\title{
Plasma trapping in the centrifuged red cells of children with severe thalassaemia
}

\author{
CLEOPATRA ECONOMOU-MAVROU 1 AND CHRISTINA TSENGHI \\ From the Paediatric Clinic of Athens University Research Laboratory
}

SYNOPSIS The amount of trapped plasma, expressed as a percentage of the packed cell volume, was determined in samples of heparinized blood from 26 children with severe thalassaemia and from 37 normal children over a wide range of artificial packed cell volumes.

There was invariably more plasma trapped among the centrifuged red cells of the thalassaemic children, the mean difference between normal and thalassaemic children being $1 \%$ of the packed cell volume.

In both normal and thalassaemic children the volume of trapped plasma, expressed as a percentage of the packed cell volume, was directly proportional to the packed cell volume.

Plasma trapping did not appear to be related to the size of the erythrocytes in either the normal or the thalassaemic children. It varied inversely with the density of the red cells, as estimated by their mean haemoglobin concentration, in the thalassaemic children.

In a previous investigation it was found that the concentration of sodium in the packed red cells was higher than normal in children with severe thalassaemia (Choremis, Economou-Mavrou, and Tsenghi, 1961). The packed red cells analysed had been obtained by spinning the blood samples at 3,000 r.p.m. for $30 \mathrm{~min}$. in a centrifuge with a radius of $15 \mathrm{~cm}$. Under these conditions packed erythrocytes consist of a mixture of cells and trapped intercellular plasma. Since so much more sodium is contained in the plasma than in the red cells, it was necessary to correct the sodium values obtained from the packed red cells for trapped plasma, for it could be argued that the higher concentrations of sodium in the thalassaemic children did not reflect a higher intracellular concentration but had resulted from a greater amount of plasma trapped among the centrifuged cells.

The majority of workers have reported that the volume of trapped plasma, expressed as a percentage of the volume of the packed red cells, varies between 3 and 5\% (Hirota, 1925; Gregersen, Gibson, and Stead, 1935; Oberst, 1935; Keith and Power, 1937; Crabtree and Maizels, 1938; Shohl and Hunter, 1941; Saifer, Hughes, and Weiss, 1942; Gregersen, Boyden, and Allison, 1945; Reeve, 1948; Reeve and

'Supported by a grant from the Société des Produits Nestlé, S.A., Vevey, Switzerland.

Received for publication 30 June 1964.
Leeson, 1950; Jackson and Nutt, 1951; Leeson and Reeve, 1951; Vazquez, Newerly, Yalow, and Berson, 1952; Chaplin and Mollison, 1952; Owen and Power, 1953; Furth, 1956; Clark and Walsh, 1960), although lower (Seyderhelm and Lampe, 1922; Ponder and Saslow, 1930; Stead and Ebert, 1941; Maizels, 1945, 1952; Keitel, Berman, Jones, and MacLachlan, 1955; Clarkson and Maizels, 1955a; Maizels and Remington, 1959; Eisenberg, 1961) and higher values have been reported (Lindhard, 1926; Chapin and Ross, 1942).

Chaplin and Mollison (1952) demonstrated that the proportion of plasma trapped among normal red cells increases directly with the height of the packed cell column. They also provided calibration curves whereby corrections for trapped plasma can be made. These observations have been confirmed by Ebaugh, Levine, and Emerson (1955) but not by other workers (Furth, 1956; Clark and Walsh, 1960).

Chaplin and Mollison (1952) also investigated plasma trapping in the presence of abnormal erythrocytes and reported that it was less with macrocytes and more with microcytes than it was with normal red cells, but not appreciably changed in the presence of anisocytosis or spherocytosis. It should be pointed out, however, that trapped plasma had been measured in only a few blood samples with abnormal red cells and at a packed cell volume which was always adjusted to $45 \%$. It was later reported that no trapping could be demonstrated in 
blood specimens with haematocrit readings below $33 \%$ (Ebaugh et al., 1955).

Two more observations have since been published on the effect of abnormal erythrocytes on plasma trapping. Clarkson and Maizels (1955b) showed that trapping was increased in blood from patients with sickle-cell anaemia. With oxygenated cells values were only slightly higher than normal but after sickling they increased by about four times. These authors also found a little more plasma trapped among the cells of one patient with the sickle-cell trait.

Using blood specimens from 12 patients with hereditary spherocytosis in a total of 74 determinations, Furth (1956) demonstrated that more plasma was trapped among spherocytes than among normal cells.

As far as we know, plasma trapping has not been investigated in thalassaemia. In view of the conflicting evidence concerning pathological cells, it was decided to measure the plasma trapped among the red cells of individuals with thalassaemia and to construct a calibration curve whereby corrections could be made for this anaemia.

\section{MATERIAL AND METHODS}

Plasma trapping was determined in blood from 26 children with severe thalassaemia, aged 2 months to 13 years, and from 37 children, of the same age group, convalescing from various diseases with no anaemia, who served as controls.

The direct method described by Chaplin and Mollison (1952) with Evans blue as a marker of trapped plasma was used. For greater accuracy thalassaemic children and controls were always investigated in pairs.

Freshly drawn heparinized blood was used in all the experiments. Since as much as $60 \%$ trapped plasma is observed in the buffy coat (Hlad and Holmes, 1953), this was always very carefully removed. Artificial mixtures of the dyed plasma and the centrifuged cells were prepared to provide cell concentrations ranging from approximately $16 \%$ to $75 \%$. With only a few exceptions plasma trapping was measured in three different artificial mixtures. In the first the packed cell volume was adjusted to $40-47 \%$ or from 55 to $75 \%$, in the second from 43 to $47 \%$ or from 33 to $38 \%$ and in the third from 24 to $29 \%$ or from 16 to $22 \%$. Results were thus obtained from a total of 72 determinations in children with thalassaemia and from a total of 97 determinations in the controls.

All artificial mixtures were spun in the same centrifuge at $1,500 \mathrm{~g}(3,000$ r.p.m., radius $15 \mathrm{~cm}$. from the centre of the rotating head to the end of the centrifuge tube) for 30 minutes. Wintrobe haematocrit tubes of $3 \mathrm{~mm}$. bore and a total blood column of $100 \mathrm{~mm}$. were used throughout this study.

The optical densities of the dyed supernatant plasma and of the dyed plasma which was extracted from the packed red cells with isotonic saline were read on a
Unicam spectrophotometer at $620 \mathrm{~m} \mu$ against an isotonic saline blank.

Extreme care was taken to avoid haemolysis during the various manipulations. Errors due to slight haemolysis are minimal with the method of Chaplin and Mollison (1952), since the plasma is highly diluted before photometric readings.

Whenever possible estimations were made in duplicate. The standard error of the mean in 14 duplicate experiments with blood from control subjects at a packed cell volume of $45 \%$ was $\pm 0 \cdot 1 \%$ and that of 11 duplicate experiments at a packed cell volume of $21 \% \pm 0.088 \%$. In children with thalassaemia the standard errors of the means at packed cell volumes of $45 \%$ and $20 \%$ were $\pm 0.15 \%$ (five duplicate experiments) and $\pm 0.084 \%$ (14 duplicate experiments) respectively. When blood was used from only one normal child in a total of 10 determinations at a packed cell volume of $23 \%$, the standard error of the mean was $\pm 0.07 \%$.

\section{RESULTS}

PLASMA TRAPPING IN BLOOD FROM CHILDREN WITH SEVERE THALASSAEMIA AND FROM CONTROLS Figure 1 contains the results which have been obtained for trapped plasma ${ }^{1}$ in blood from thalassaemic children and from controls at artificial packed cell volumes ranging between $10 \%$ and $75 \%$. At packed cell volumes lying within the normal range the present figures for the controls were comparable to those of the majority of workers who used Evans blue to measure plasma trapping in blood with a normal packed cell volume collected from healthy subjects (Gregersen et al., 1935; Shohl and Hunter, 1941; Stead and Ebert, 1941 ; Maizels, 1945; Barnes, Loutit, and Reeve, 1948; Jackson and Nutt, 1951; Maizels, 1952). Over the entire range of packed cell volumes examined the figures for the controls were a little lower than those of Chaplin and Mollison (1952) for blood from healthy subjects which was investigated under conditions identical with those of the present study.

Figure 1 also demonstrates that plasma trapping increased as the packed cell volume increased. There was a wide variation in the values for trapped plasma at any given packed cell volume, but the relationship between trapped plasma and the packed cell volume can be seen to be linear over the entire range examined. This was true of blood from both controls and children with severe thalassaemia. In the latter, individual variation in the figures for trapped plasma at any given packed cell volume was even greater than that observed in the controls. However, in spite of some degree of overlapping, there was invariably

${ }^{1}$ In this study plasma trapping has been expressed as a percentage of the packed red cell volume. 


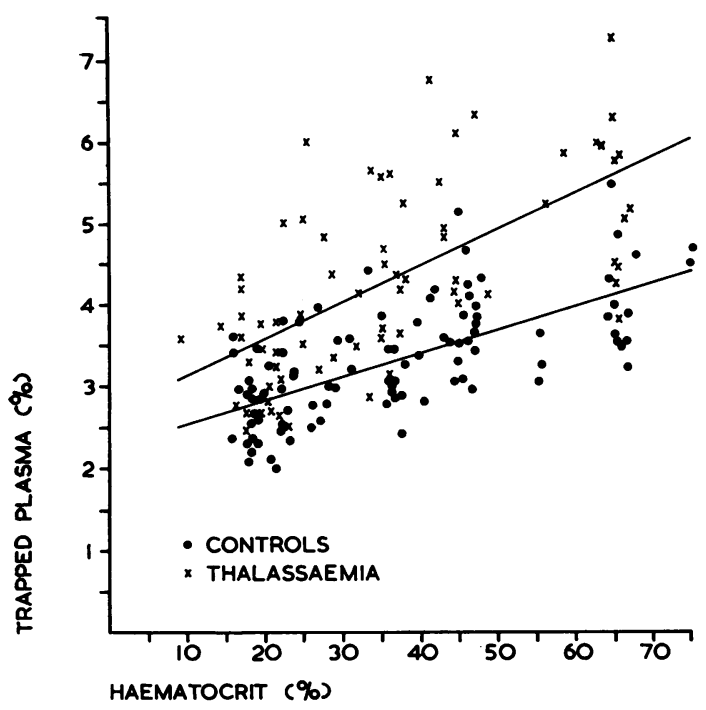

FIG. 1. Trapped plasma, expressed as a percentage of the packed red cell volume, plotted against the height of the cell column.

more plasma trapped among the red cells of the thalassaemic children than there was among the cells of their paired controls (see appendix).

EFFECT OF CELl SIZE ON PLASMa TRAPPING Some evidence has been presented by Chaplin and Mollison (1952) that in blood containing pathological cells, the size of the cells may be an important factor determining plasma trapping during centrifugation, the smaller cells trapping more plasma than the larger cells. More recently, however, Furth (1956) observed that trapping increased when blood from normal individuals or from patients with hereditary spherocytosis was incubated at $37^{\circ} \mathrm{C}$. for 24 hours and it is known that these conditions greatly increase the size of the cells in both normal individuals and patients with hereditary spherocytosis (Selwyn and Dacie, 1954; Young, Izzo, Altman, and Swisher, 1956). Plasma trapping was further increased when the blood was incubated for another 24 hours (Furth, 1956) during which the cell volume is known to shrink to its initial value (Selwyn and Dacie, 1954).

In order to determine the effect of cell size on plasma trapping, the mean corpuscular volume was calculated in 22 of the controls and in 21 of the children with severe thalassaemia and was compared with the trapped plasma in the packed cell column.

Table I shows that the range of the mean corpuscular volumes was wide in the group of thalassaemic children and that the mean value of these children was not, on the average, much different from that of
TABLE I

MEAN CORPUSCULAR VOLUMES AND MEAN CORPUSCULAR CONCENTRATIONS OF HAEMOGLOBIN IN NORMAL CHILDREN AND CHILDREN WITH SEVERE THALASSAEMIA M.C.V. $\left(\mu^{3}\right) \quad$ M.C.H.C. $(\%)$

Normal children 4 mth. to $12 \mathrm{yr}$.

Maximum

Minimum

Mean

S.D.

No. of observations

$\begin{array}{rc}88 & 37 \cdot 7 \\ 74 & 30 \cdot 8 \\ 80 & 34 \cdot 4 \\ \pm 5 & \pm 3 \cdot 3 \\ 22 & 22\end{array}$

Children with severe thalassaemia $2 \mathrm{mth}$. to $11 \mathrm{yr}$.

Maximum

Minimum

Mean

S.D.

No. of observations

$\begin{array}{rr}110 & 37 \cdot 6 \\ 58 & 23 \cdot 3 \\ 85 & 32 \cdot 8 \\ +12 & \pm 3 \cdot 9 \\ 21 & 21\end{array}$

the normal children. This finding will be discussed later.

Figure 2 illustrates that there was no relationship between plasma trapping and the mean corpuscular volume in either the controls or the thalassaemic children (see appendix).

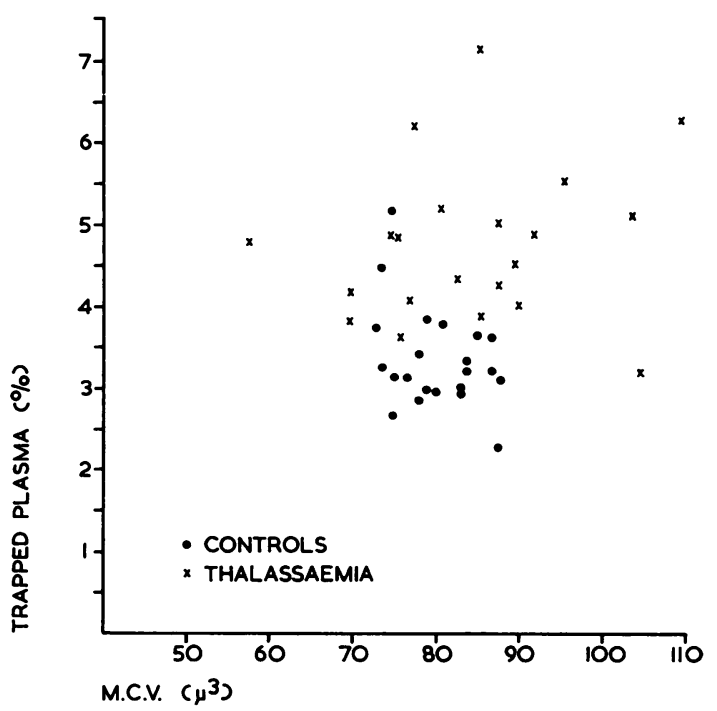

FIG. 2. Trapped plasma, expressed as a percentage of the packed red cell volume, plotted against the mean corpuscular volume. All values are for trapping at a P.C.V. of $45 \%$.

EFFECT OF CELL DENSITY ON PLASMA TRAPPING Previous workers have suggested that the density of the red cells is one of the factors governing cell packing during centrifugation, the heavier cells packing more tightly than the lighter cells (Ponder, 1948; Owen and Power, 1953). Young erythrocytes are known to be lighter than older erythrocytes (Granick, 1949; Keitel et al., 1955; Constandoulakis and Kay, 
1959; Borun, Figueroa, and Perry, 1957) and Leeson and Reeve (1951) have reported a statistically significant increase in the plasma trapped among the centrifuged cells of rabbits with experimental acute post-haemorrhagic anaemia. This was probably associated with the high proportion of reticulocytes in the blood in this anaemia.

Indirect information about the density of the red cells may be obtained if their water content is known. The latter varies inversely with the mean concentration of haemoglobin in the cell (Choremis et al., 1961).

In an attempt to evaluate the effect of cell density on plasma trapping, the latter was compared with the mean corpuscular haemoglobin concentration in 22 of the controls and 21 of the children with thalassaemia. Table I demonstrates that the mean corpuscular haemoglobin concentration in the thalassaemic children was, on the average, only slightly lower than normal. In most of these children it was normal or slightly reduced, the reduction being considerable in only one case. These findings will also be discussed later.

In Fig. 3 the figures for trapped plasma have been plotted against the mean corpuscular haemoglobin concentrations. It can be seen that plasma trapping varied inversely with the mean corpuscular haemoglobin concentration in the thalassaemic children. However, there was no such relationship in the group of controls (see appendix).

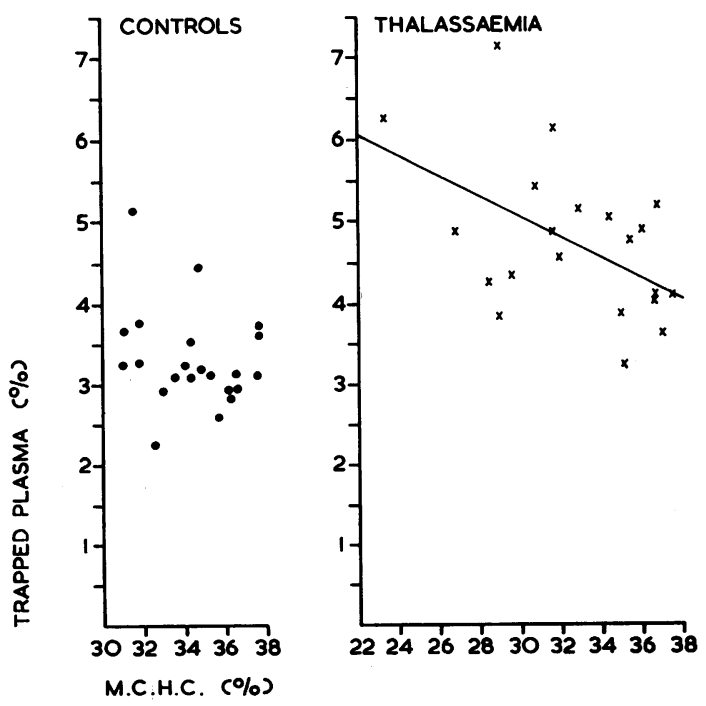

FIG. 3. Trapped plasma, expressed as a percentage of the packed red cell volume, plotted against the mean corpuscular haemoglobin concentration. All values are for trapping at a P.C.V. of $45 \%$.

\section{DISCUSSION}

The results of this study show that erythrocytes from children with severe thalassaemia pack less efficiently during centrifugation than do erythrocytes from normal children. They also confirm earlier observations (Chaplin and Mollison, 1952; Ebaugh et al., 1955) that the percentage of the packed cell volume in the haematocrit tube occupied by trapped plasma is directly proportional to the height of the red cell column.

Why red cells from children with severe thalassaemia pack less efficiently than normal cells is a matter that cannot be settled from the results of this study. The external physical variables affecting cell packing during centrifugation, which include the relative centrifugal force and the shape and size of the haematocrit tube, may be neglected, since blood from both normal and thalassaemic children was always tested under identical conditions.

An attempt was made to correlate plasma trapping with the intrinsic properties of the red cells which influence their packing. These include their size (Ponder, 1948; Chaplin and Mollison, 1952), their shape (Clarkson and Maizels, 1955b; Furth, 1956), their density (Ponder, 1948; Owen and Power, 1953; Furth, 1956), and their deformability (Furth, 1956).

The group of controls in this study included six infants in whom a rather small mean corpuscular volume was normal for their age (Wintrobe, 1961). The thalassaemic children had mean cell volumes ranging from $58 \mu^{3}$ to as high as $110 \mu^{3}$. Although thalassaemia is generally believed to belong to the microcytic anaemias, the mean corpuscular volume is not invariably low. It may, in fact, be normal (Smith, 1943; Smith, 1948; Minnich, Na-Nakorn, Chongchareonsuk, and Kochaseni, 1954; Israels, Suderman, and Hoogstraten, 1955; Matoth, Shamir, and Freundlich, 1955; Smith, Schulman, Ando, and Stern, 1955; Sturgeon and Finch, 1957; Vullo and Tunioli, 1958; Fessas, 1964) or even high (Smith, 1943; Smith, 1948; Minnich et al., 1954), and during the last few years cases have been reported of megaloblastic anaemia complicating thalassaemia (Crosby and Sacks, 1949; Goldberg and Schwartz, 1954; Chanarin, Dacie, and Mollin, 1959; Fessas, 1959) which was attributed to folic acid deficiency (Goldberg and Schwartz, 1954; Fessas, 1959).

The normal or slightly reduced mean corpuscular haemoglobin concentrations found in the present group of children with thalassaemia are not in general agreement with those previously observed by other investigators. The mean corpuscular haemoglobin concentration is usually low in thalassaemia (Marmont and Bianchi, 1947; Minnich et al., 1954; Wintrobe, 1961 ; Sturgeon and Finch, 1957; Lie-Ingo 
Luan Eng, Kho Lien Keng, Liem Djwan Lioe, and Oei Oen Bie, 1959). However, this is not the first time that patients with thalassaemia have been found to have relatively normal mean corpuscular haemoglobin concentrations (Smith, 1943; Dhayagude, 1944; Smith, 1948; Valentine and Neel, 1948; Schwartz and Mason, 1949; Matoth et al., 1955; Siddoo, Siddoo, Chase, Morgan-Dean, and Perry, 1956; Vullo and Tunioli, 1958; Lie-Ingo Luan Eng et al., 1959; Lehmann, 1959; Choremis et al., 1961; Fessas, 1964).

In the present study plasma trapping did not appear to be related to the mean corpuscular volume in either the normal or the thalassaemic children, but was found to be inversely proportional to the density of the red cells, as estimated by their mean haemoglobin concentration. However, this was true only of blood from thalassaemic children, not of blood from normal children, probably because the range of the mean corpuscular haemoglobin concentrations in the group of normal children was too narrow to allow the measurement of the correlation between plasma trapping and the mean corpuscular haemoglobin concentration. It is difficult to conceive that density is not important in determining plasma trapping during centrifugation. Suggestive along these lines is the presence of reticulocytosis in all four types of anaemia in which trapping has been shown to be increased, namely, in hereditary spherocytosis, sickle-cell anaemia, experimental acute post- haemorrhagic anaemia, and thalassaemia. Reticulocytes are lighter than older erythrocytes and their presence in increased numbers may be expected to reduce the effectiveness of cell packing during centrifugation.

It is even more difficult to evaluate the effect of the shape and/or deformability of the red cells on plasma trapping. Other workers have demonstrated that erythrocytes with as widely different shapes as the sickle cell (Clarkson and Maizels, 1955b) and the spherocyte (Furth, 1956) trap more plasma than do normal cells. Furth (1956) suggested that plasma trapping could be predicted to be increased among spherocytes on the very basis of increased sphering. On the other hand, increased trapping among the sickle cells may be related to their inability to form rouleaux because of their peculiar shape. The extreme variation in the shape of the erythrocytes in severe thalassaemia defies any attempt even to speculate on the effect of their shape on plasma trapping.

The possibility that increased plasma trapping in thalassaemia reflected errors associated with the use of Evans blue was also considered. Evans blue forms a complex with albumin and it has been suggested that measurements of trapped plasma may be expected to be satisfactory only as long as the albumin in the plasma is not overloaded with the dye and that even so, some of the dye may be adsorbed on the red cells (Maizels and Remington, 1959). The albumin fraction is generally decreased in children with severe thalassaemia (Allamanis, 1955). Furthermore, in these children plasma bilirubin, which is also carried by the albumin fraction, is usually increased. These conditions would be expected to increase the amount of Evans blue combined with the cells and to give erroneously high figures for trapped plasma, if all the dye remaining within the cell column were extracted for photometric reading (Maizels and Remington, 1959). Nevertheless, Evans blue was extracted in this study with isotonic saline which is incapable of removing the dye which may have combined with the cells (Maizels and Remington, 1959).

We are grateful to Dr. M. Gregoriou for technical assistance.

\section{APPENDIX}

Statistical treatment of the results of the present investigation yielded the following results.

RELATIONSHIP BETWEEN PLASMA TRAPPING AND THE PACKED CELL VOLUME A direct linear correlation was found between these two variables. In the group of controls $r=0.643$ and in the group of thalassaemic children $r=0.639$. These values are statistically significant. In the group of controls $t=8 \cdot 18$ and in the group of thalassaemic children $t=6.95(P<0.01)$.

The slope of the best line drawn through the points, calculated by the method of least squares, was steeper in thalassaemia but covariance analysis showed that the difference between the two slopes was only probably significant $\left(F_{1} 1 / 166=5 \cdot 671, P=0.05\right)$.

DIFFERENCE IN PLASMA TRAPPING BETWEEN NORMAL AND THALASSAEMIC CHILDREN Covariance analysis showed that the difference in the mean levels of the best lines drawn through the points, calculated by the method of least squares, between the normal and the thalassaemic children was highly significant $\left(F_{1} 1 / 166=69 \cdot 364\right.$, $P<0.001)$.

RELATIONSHIP BETWEEN PLASMA TRAPPING AND THE MEAN CORPUSCULAR VOLUME No relationship was found between these two variables in either the normal or the thalassaemic children. In the former $\mathrm{r}=-0.223<$ $-0.423, P=0.05$, and in the latter $r=0.178<0.433$, $P=0.05$.

RELATIONSHIP BETWEEN PLASMA TRAPPING AND THE MEAN CORPUSCULAR HAEMOGLOBIN CONCENTRATION An inverse relationship was found between these two variables only in the group of thalassaemic children $(\mathrm{r}=-0.478, \mathrm{P}<0.05,>0.02)$. 


\section{REFERENCES}

Allamanis, J. (1955). Electrophoretic Studies of Serum Proteins in Congenital Haemolytic Anemias. Thesis, University of Athens.

Barnes, D. W. H., Loutit, J. F., and Reeve, E. B. (1948). Clin. Sci., $7,135$.

Borun, E. R., Figueroa, W. G., and Perry, S. M. (1957). J. clin. Invest., 36, 676.

Chanarin, I., Dacie, J. V., and Mollin, D. L. (1959). Brit. J. Haemat., 5,245 .

Chapin, M. A., and Ross, J. F. (1942). Amer. J. Physiol., 137, 447.

Chaplin, H. Jr., and Mollison, P. L. (1952). Blood, 7, 1227.

Choremis, C., Economou-Mavrou, C., and Tsenghi, C. (1961). J. clin. Path., 14, 637.

Clark, P., and Walsh, R. J. (1960). Aust. J. exp. Biol. med. Sci., 38, 451.

Clarkson, E. M., and Maizels, M. (1955a). J. Physiol. (Lond.), 129, 476.

-

Constandoulakis, M., and Kay, H. E. M. (1959). J. clin. Path., 12 , 312.

Crabtree, M., and Maizels, M. (1938). Biochem. J., 32, 74.

Crosby, W. H., and Sacks, H. J. (1949). Blood, 4, 1267.

Dhayagude, R. G. (1944). Amer. J. Dis. Child., 67, 290.

Ebaugh, F. G. Jr., Levine, P., and Emerson, C. P. (1955). J. Lab. clin. Med., 46, 409.

Eisenberg, S. (1961). J. clin. Invest., 40, 1036.

Fessas, P. (1959). Thalassaemia and the alterations of the haemoglobin pattern. In Abnormal Haemoglobins. A Symposium organized by C.I.O.M.S., edited by J. H. P. Jonxis and J. F. Delafresnaye, p. 134. Blackwell, Oxford.

- (1964). The Haemoglobin Synthesis Defect in Thalassaemia. Thesis, University of Athens.

Furth, F. W. (1956). J. Lab. clin. Med., 48, 421.

Granick, S. (1949). Blood, 4, 404.

Goldberg, M. A., and Schwartz, S. O. (1954). Ibid., 9, 648.

Gregersen, M. I., Boyden, A. A., and Allison, J. B. (1945). Fed. Proc., $4,27$.

- Gibson, J. J., and Stead, E. A. (1935). Amer. J. Physiol., 113, 54. Hirota, K. (1925). J. Biophys. (Tokyo), 1, 233.

Hlad, C. J. Jr., and Holmes, J. H. (1953). J. appl. Physiol., 5, 457.

Israels, L. G., Suderman, H. J., and Hoogstraten, J. (1955). Lancet, $2,1318$.
Jackson, M. D., and Nutt, M. E. (1951). J. Physiol. (Lond.), 115, 196. Keitel, H. G., Berman, H., Jones, H., and MacLachlan, E. (1955). Blood, 10, 370.

Keith, N. M., and Power, M. H. (1937). Amer. J. Physiol., 120, 203. Leeson, D., and Reeve, E. B. (1951). J. Physiol. (Lond.), 115, 129. Lehmann, H. (1959). Brit. med. Bull., 15, 40.

Lie-Ingo Luan Eng, Kho Lien Keng, Liem Djwan Lioe, and Oei Oen Bie (1959). Acta haemat. (Basel), 21, 102.

Lindhard, J. (1926). Amer. J. Physiol., 76, 497.

Maizels, M. (1945). Quart. J. exp. Physiol., 33, 129.

- (1952). J. Physiol. (Lond.), 116, 38P.

and Remington, M. (1959). Ibid., 145, 658.

Marmont, A., and Bianchi, V. (1947). Pathologica, 39, 9.

Matoth, Y., Shamir, Z., and Freundlich, E. (1955). Blood, 10, 176

Minnich, V., Na-Nakorn, S., Chongchareonsuk, S., and Kochaseni, S. (1954). Ibid., 9, 1.

Oberst, F. W. (1935). J. biol. Chem., 108, 153.

Owen, C. A. Jr., and Power, M. H. (1953). J. appl. Physiol., 5, 323.

Ponder, E. (1948). Haemolysis and Related Phenomena. Grune and Stratton, New York. and Saslow, G. (1930). J. Physiol. (Lund.), 70, 18.

Reeve, E. B. (1948). Nutr. Abstr. Rev., 17, 811. and Leeson, D. (1950). Proc. 18th int. physiol. Congr., p. 408

Saifer, A., Hughes, J., and Weiss, E. (1942). J. biol. Chem., 146, 527. Schwartz, S. O., and Mason, J. (1949). Blood, 4, 706.

Selwyn, J. G., and Dacie, J. V. (1954). Ibid., 9, 414.

Seyderhelm, R., and Lampe, W. (1922). Z. ges. exp. Med., 30, 403.

Shohl, A. T., and Hunter, T. H. (1941). J. Lab. clin. Med., 26, 1829.

Siddoo, J. K., Siddoo, S. K., Chase, W. H., Morgan-Dean, L., and Perry, W. H. (1956). Blood, 11, 197.

Smith, C. H. (1943). Amer. J. Dis. Child., 65, 681. (1948). Ibid., 75, 505.

, Schulman, I., Ando, R. E., and Stern, G. (1955). Blood, 10, 707. Stead, E. A., and Ebert, R. V. (1941). Amer. J. Physiol., 132, 411.

Sturgeon, P., and Finch, C. A. (1957). Blood, 12, 64.

Valentine, W. N., and Neel, J. V. (1948). Amer. J. med. Sci., 215, 456.

Vazquez, O. N., Newerly, K., Yalow, R. S., and Berson, S. A. (1952). J. Lab. clin. Med., 39, 595.

Vullo, C., and Tunioli, A. M. (1958). Blood, 13, 803.

Young, L. E., Izzo, M. J., Altman, K. I., and Swisher, S. N. (1956). Ibid., 11, 977.

Wintrobe, M. M. (1961). Clinical Haematology, 5th ed. Lea and Febiger, Philadelphia. 